\title{
ANNALS OF COMMUNISM
}

Each volume in the series Annals of Communism will publish selected and previously inaccessible documents from former Soviet state and party archives in a narrative that develops a particular topic in the history of Soviet and international communism. Separate English and Russian editions will be prepared. Russian and Western scholars work together to prepare the documents for each volume. Documents are chosen not for their support of any single interpretation but for their particular historical importance or their general value in deepening understanding and facilitating discussion. The volumes are designed to be useful to students, scholars, and interested general readers. 
Jonathan Brent, Yale University Press

PROJECT MANAGER

Vadim A. Staklo

AMERICAN ADVISORY COMMITTEE

Ivo Banac, Yale University

Zbigniew Brzezinski, Center for

Strategic and International Studies

William Chase, University of Pittsburgh

Friedrich I. Firsov, former head of the

Comintern research group at

RGASPI

Sheila Fitzpatrick, University of

Chicago

Gregory Freeze, Brandeis University

John L. Gaddis, Yale University

J. Arch Getty, University of California, Los Angeles

Jonathan Haslam, Cambridge University

\section{RUSSIAN ADVISORY COMMITTEE}

K. M. Anderson, Moscow State University

N. N. Bolkhovitinov, Russian Academy of Sciences

A. O. Chubaryan, Russian Academy of Sciences

V. P. Danilov, Russian Academy of Sciences

A. A. Fursenko, secretary, Department of History, Russian Academy of Sciences (head of the Russian Editorial Committee)

V. P. Kozlov, former director, Rosarkhiv

N. S. Lebedeva, Russian Academy of Sciences
Robert L. Jackson, Yale University

Norman Naimark, Stanford University

Gen. William Odom (deceased), Hudson Institute and Yale University

Daniel Orlovsky, Southern Methodist University

Timothy Snyder, Yale University

Mark Steinberg, University of Illinois, Urbana-Champaign

Strobe Talbott, Brookings Institution

Mark Von Hagen, Arizona State University

Piotr Wandycz, Yale University

S. V. Mironenko, director, State Archive of the Russian Federation (GARF)

O. V. Naumov, director, Russian State Archive of Social and Political History (RGASPI)

E. O. Pivovar, Moscow State University

V. V. Shelokhaev, president, Association ROSSPEN

Ye. A. Tyurina, director, Russian State Archive of the Economy (RGAE) 


\title{
Sedition
}

Everyday Resistance in the Soviet Union under Khrushchev and Brezhnev

\author{
Edited by \\ Vladimir A. Kozlov, Sheila Fitzpatrick, and \\ Sergei V. Mironenko \\ Compiled by V. A. Kozlov and O. V. Edelman \\ with assistance from E. Yu. Zavadskaia \\ English edition edited and introduced by Sheila Fitzpatrick \\ Translated by Olga Livshin \\ English edition annotated by Andrew Janco
}

\section{Yale}

UNIVERSITY PRESS

New Haven \& London 
This volume has been prepared with the cooperation of the State Archive of the Russian Federation (GARF) of the Federal Archival Agency of Russia (Rosarkhiv) in the framework of an agreement concluded between GARF and Yale University Press.

Published with assistance from the foundation established in memory of William McKean Brown.

Copyright (C) 20I I by Yale University.

All rights reserved.

This book may not be reproduced, in whole or in part, including illustrations, in any form (beyond that copying permitted by Sections I07 and I08 of the U.S. Copyright Law and except by reviewers for the public press), without written permission from the publishers.

Designed by James J. Johnson and set in Sabon Roman type by The Composing Room of Michigan, Inc., Grand Rapids, Michigan. Printed in the United States of America by Sheridan Books, Ann Arbor, Michigan.

\section{Library of Congress Cataloging-in-Publication Data}

Kramola-inakomyslie v SSSR pri Khrushcheve i Brezhneve, I953-I982 gg. English.

Sedition : everyday resistance in the Soviet Union under Khrushchev and Brezhnev / edited by Vladimir A. Kozlov, Sheila Fitzpatrick, and Sergei V. Mironenko ; compiled by V. A. Kozlov and O. V. Edelman ; with assistance from E. Yu. Zavadskaia ; English edition edited and introduced by Sheila Fitzpatrick ; translated by Olga Livshin ; English edition annotated by Andrew Janco.

$$
\text { p. cm. - (Annals of communism) }
$$

Translation of: Kramola-inakomyslie v SSSR pri Khrushcheve i Brezhneve, I953I982 gg. : rassekrechennye dokumenty Verkhovnogo suda i Prokuratury SSSR. Moscow : Materik, 2005.

ISBN 978-0-300-I I I 69-9

I. Human rights-Soviet Union-History-Sources. 2. Dissenters-Soviet UnionHistory-Sources. 3. Government, Resistance to-Soviet Union-History-Sources. 4. Propaganda, Anti-Soviet-History-Sources. 5. Evidence, Criminal-Soviet Union -History-Sources. 6. Soviet Union-Politics and government-I953-I985Sources. I. Kozlov, V. A. (Vladimir Aleksandrovich) II. Fitzpatrick, Sheila. III. Mironenko, S. V. IV. Edel'man, O. V. (Ol'ga V.) V. Zavadskaia, E. IU.

VI. Soviet Union. Verkhovnyi Sud. VII. Soviet Union. Prokuratura. VIII. Title.

JC599.S65 K 73 I 320 II

$323^{\prime} .044094709045-\mathrm{dc} 22$

2010021558

A catalogue record for this book is available from the British Library.

This paper meets the requirements of ANSI/NISO Z39.48-I992 (Permanence of Paper).

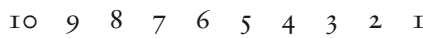


Yale University Press gratefully acknowledges the financial support given for this publication by the John M. Olin Foundation, the Lynde and Harry Bradley Foundation, the Historical Research Foundation, Roger Milliken, Lloyd H. Smith, Keith Young, Keith Young, Jr., the William H. Donner Foundation, Joseph W. Donner, Jeremiah Milbank, and the David Woods Kemper Memorial Foundation. 
This page intentionally left blank 